\title{
GENOTYPE CHARACTERIZATION OF Leishmania (Viannia) braziliensis ISOLATED FROM HUMAN AND CANINE BIOPSIES WITH AMERICAN CUTANEOUS LEISHMANIASIS
}

Lasaro Teixeira FERREIRA(1), Aparecida Helena de Souza GOMES(2) \& Vera Lucia PEREIRA-CHIOCCOLA(1)

\begin{abstract}
SUMMARY
Introduction: American tegumentary leishmaniasis (ATL) can be caused by Leishmania (Viannia) braziliensis complex. The evolution of ATL initially results in lesions and can develop into disseminated or diffuse forms. The genetic diversity of $L$. (V.) braziliensis in some endemic areas of Brazil has been poorly studied, such as in the state of São Paulo. This study analyzed the genetic diversity of $L$. (V.) braziliensis isolates collected from patients and dogs with LTA from the state of São Paulo. Methods: Leishmaniasis diagnosis was determined by PCR. The 132 biopsies were collected in different regions of Sao Paulo State, Brazil (36 municipalities). The genetic characterization of $L$. (V.) braziliensis isolates was tested by RFLP-PCR using DNA extracted from biopsies. The primer set amplified a specific region of Leishmania internal transcribed spacers of the ribosomal DNA locus. Results: Of the 132 samples, 52 (40\%) were completely genotyped by RFLP-PCR (44 from human patients and eight from dogs). The results showed nine distinct patterns. The majority of the genotyped samples were from Sorocaba (30), and the others were distributed among 14 other municipalities. The first pattern was more frequent ( 29 samples), followed by pattern 2 (nine samples) and pattern 3 (three samples). Patterns 4, 6, 7, 8 and 9 were composed of two samples each and pattern 5 of one sample. Conclusion: These results suggest that polymorphic strains of $L$. (V.) braziliensis circulate in the state of São Paulo. These data agree with studies from other regions of Brazil, showing great variability among the natural populations of endemic foci.
\end{abstract}

KEYWORDS: American cutaneous leishmaniasis; Leishmania (Viannia) braziliensis; RFLP-PCR; Polymorphism.

\section{INTRODUCTION}

The Leishmania genus causes leishmaniasis, which constitutes a variety of chronic diseases. There is a wide spectrum of clinical forms, including those affecting the skin, mucosa, or internal organs ${ }^{16,18}$.

The subgenera Leishmania Viannia is the causative agent of newworld cutaneous leishmaniasis, comprising the species $L$. (V.) braziliensis, $L$. (V.) panamensis and $L$. (V.) guyanesis, among others ${ }^{18,26}$. Infections by these species cause three clinical types of American tegumentary leishmaniasis (ATL): localized cutaneous, mucosal, and disseminated leishmaniasis. Cutaneous lesions are restricted to the entry site of the parasites, whereas the mucosal strain is defined by its spreading to the mucosal surfaces of the upper digestive and airway tracts. Disseminated leishmaniasis is characterized by large-scale spreading to distant cutaneous sites $2,14,15,24$.

Despite the fact that cutaneous leishmaniasis is caused by at least seven different Leishmania species in Brazil, the vast majority of cases are caused by the $L$. (V.) braziliensis sub-genera, which can be transmitted by different phlebotomine sandfly vectors via animal reservoirs across a wide geographic distribution ${ }^{1,7,16,18,28}$.

ATL is widely distributed across the Americas. Between 2001 and 2011 , around 270,500 cases were reported, with an average of 27,500 new cases/year. Around 3 - 5\% of patients who develop cutaneous lesions are also susceptible to mucosal leishmaniasis ${ }^{23,30}$. In the state of São Paulo there are approximately 400 new cases per year. Another substantial problem is the urbanization of the infection. Autochthonous cases have been reported in urban areas. The incidence of peri-urban and urban cases has been increasing. Approximately $10 \%$ of the population living in endemic areas is at risk of acquiring the infection ${ }^{29}$. ATL is also considered one of the most common dermatological syndromes diagnosed in travelers (or tourists) who have visited endemic areas ${ }^{15}$.

The life cycle of $L$. (V.) braziliensis includes different reservoirs, such as humans and wild and domestic mammals, as well as various vector species. Therefore, Leishmania strains can be maintained in both rural and urban settings, thereby affecting the epidemiology of the infection. Due to the proximity of dogs and humans, studies have shown the important role of domestic dogs in ATL ${ }^{19,21}$. Studies using molecular techniques to characterize $L$. (V.) braziliensis populations have contributed to a better 


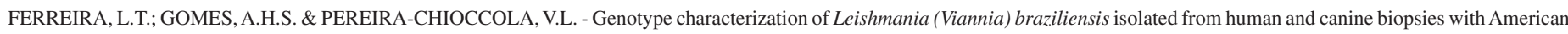
cutaneous leishmaniasis. Rev. Inst. Med. Trop. Sao Paulo, 57(3): 257-262, 2015.

understanding of the abilities of these parasites and their vectors in adapting to changes in their original forest habitats, and the consequent public health implications ${ }^{13}$.

Despite the significance of ATL to the Brazilian public health system, the genetic diversity of $L$. (V.) braziliensis in some endemic areas of Brazil has been poorly researched, as in the state of São Paulo. Therefore, this study aims to analyze the genetic diversity of a $L$. (V.) braziliensis population collected from patients and dogs in the state of São Paulo with cutaneous lesions, avoiding in vitro cultivation. The reason for evaluating polymorphism in humans and dogs was due to the importance of both species within the parasite's life cycle. The results indicate a high variability in isolates collected in patients and dogs from the state of São Paulo. Additionally, this study has shown the possibility of performing genotyping directly on clinical samples without having to isolate the parasite.

\section{MATERIAL AND METHODS}

Human and dog samples: The selection of positive samples was made in biopsies received by an in-house Laboratory over a period of nine years $(2003$ - 2012). The biopsies were collected by medical or veterinary health services. The human or canine lesions were cleansed with antiseptics after the administration of a local anesthetic. The borders of the lesions were scraped or smears of material were obtained by a punch biopsy of the lesions and immediately added to tubes containing 1-2 $\mathrm{mL}$ of a sterile $0.85 \% \mathrm{NaCl}$ and $200 \mu \mathrm{g} / \mathrm{mL}$ gentamicin solution, sent to the laboratory within 48 hours and promptly processed to confirm clinical diagnosis. All biopsies recorded were from patients with the cutaneous clinical form. Samples were tested by routine diagnosis, which included molecular and parasitological methods. The methodologies applied were PCR, using two different sets of primers, and a parasitological method (microscopic observation). These DNA samples were from patients and dogs living in 36 different municipalities and endemic areas for ATL in the state of São Paulo, Brazil (Alumínio, Aruja, Avaré, Bauru, Bragança Paulista, Cajamar, Campinas, Caraguatatuba, Cerquilho, Conhal, Cubatão, Guapiara, Guarulhos, Ibirá, Ilha Bela, Indaiatuba, Iperó, Iporanga, Itapera, Itupeva, Jaboticabal, Jundiaí, Mairiporã, Marília, Miracatu, Mirandópolis, Mogi Guaçu, Monte Mor, Pilar do Sul, Ribeira, Salto, São Paulo, Sorocaba, Suzano, Tatuí, Tietê). Epidemiological registers of the different Public Dermatology Clinics or Centers for Zoonosis Control were analyzed to determine the locality of the Leishmania infection of each patient (or dog).

Ethical considerations: This study was performed according to the recommendations of the Human Ethics Committee (CONEP-IAL) and "Sociedade Brasileira de Ciência em Animais de Laboratório/Colégio Brasileiro de Experimentação Animal" (SBCAL/COBEA). Both Ethic Committees of Instituto Adolfo Lutz have approved of this study.

Leishmania strains: For genotype standardization, the following WHO standard Leishmania strains were used: L. (V.) guyanensis (MHOM/BR/1975/M4147), L. (L.) amazonensis (IFLA/BR/1967/PH8), L. (L.) major (MHOM/SU/1973/5-ASKH), L. (L.) infantum (MHOM/ BR/1974/PP75), and L. (V.) braziliensis (MHOM/BR/1975/M2903). The Leishmania strains were maintained by serial passages and grown at 24 ${ }^{\circ} \mathrm{C}$ in M-199 medium, supplemented with $10 \%$ calf serum and $0.25 \%$ hemin $^{25}$. In the log phase, 1 x $10^{8}$ parasites were harvested and washed twice in phosphate-buffered saline $(\mathrm{pH} 7.2)$ at $1,000 \mathrm{~g}$ for $10 \mathrm{~min}$. The parasite pellets were used for DNA extraction. $L$. $(V$.) braziliensis strain DNA also was used in reactions as a positive control.

DNA purification: Before performing DNA extraction, clinical samples and WHO Leishmania reference strains were crushed and digested in a lysis buffer until tissue lysis was complete, (This- $\mathrm{HCl}$, $10 \mathrm{mM}, \mathrm{pH}$ 8.0; EDTA 10mM; SDS, 0,5\%; N-laurilsarcozil, 0.01\%; proteinase $\mathrm{K}, 100 \mu \mathrm{g} / \mathrm{mL}$ ) by incubation in water bath at $56{ }^{\circ} \mathrm{C}$. Then, DNA molecules were extracted by a QIAamp DNA Mini Kit (Qiagen), according to the manufacturer's instructions. DNA concentration and purity was determined by the ratio of O. D. at 260 and $280 \mathrm{~nm}$ in a NanoDrop ND1000 (Thermo Scientific).

\section{Routine Leishmania diagnosis}

Parasitological diagnosis: Skin biopsy imprints were plated onto a glass slide, fixed with methanol and stained with Giemsa ${ }^{11}$. The presence of amastigotes was observed microscopically with an immersion objective $(\times 1,000)$.

PCR targets for Leishmania and internal controls: The Leishmania genus was identified by a 120-bp PCR product, amplified from a conserved region of kDNA minicircles of Leishmania spp., using the primer set $150 / 152^{23}$. L. (V.) braziliensis was identified by an amplified fragment of 146-149 bp from the multicopy spliced leader (SL) RNA gene using the primer set LU-5A/LB-3C, which amplifies a 146-149 bp sequence from the $\mathrm{SL}^{12,17}$. These tests were carried out under the same aforementioned conditions ${ }^{11,12}$. To check PCR inhibitors, canine and human samples were assayed using a reference gene, whose primer sets were GAPDH4F/GAPDH4R and $\beta 1-\beta 2$, respectively, in the same conditions as previously described ${ }^{3,11}$. After the thermal cycles, PCR products were electrophoresed in $2 \%$ agarose gel and stained with ethidium bromide. DNA fragments were made visible under UV illumination.

L. (V.) braziliensis genotyping by RFLP-PCR (restriction fragment length polymorphism-PCR): Originally, 132 DNA extracts from biopsies, positive for $L$. (V.) braziliensis, were analyzed for genotype determination. PCR was used for diagnosis and genotyping directly from clinical DNA samples. Each test was performed by adding $5 \mu \mathrm{L}$ from each DNA template and 25 pmol from each primer for a final volume of $25 \mu \mathrm{L}$. The amplifications were carried out with a kit purchased from Promega (Go Taq Green Master Mix). The PCR mix $(12.5 \mu \mathrm{L})$ was composed of one unit of Taq DNA polymerase, $10 \mathrm{mM}$ Tris- $\mathrm{HCl}, \mathrm{pH} 8.5 ; 50 \mathrm{mM} \mathrm{KCl} ; 1.5 \mathrm{mM} \mathrm{MgCl}_{2}$; and $200 \mathrm{mM}$ of each dNTP. In genotype reactions the primer set used was IR1/ IR2 (5'-GCTGTAGGTGAACCTGCAGCAGCTGGATCATT-3' and 5'-GCGGGTAGTCCTGCCAAACACTCAGGTCTG-3'), which amplified a 1-1.2-kb sequence from the ITS region between the small and large subunits of the rDNA locus in a temperature annealing at $56^{\circ} \mathrm{C}^{5}$. PCR-amplified products were digested with a HhaI restriction enzyme, which were separated by electrophoresis in an $8 \%$ polyacrylamide gel and stained with ethidium bromide. DNA fragments were made visible under UV illumination. The images from reactions for diagnosis and genotyping were analyzed by a MiniBIS Gel Imager and Documentation system (BioSystematica). The size of the fragments was based on a comparison with molecular-weight size markers. In genotyping reactions, the banding patterns were used to group the isolates into genotypes with 
the same banding pattern for the restriction enzyme.

Quality assurance: Each DNA extraction batch included a DNA extraction from Leishmania-free eukaryotic samples as a negative control. In each reaction, a tube containing nuclease-free water and PCR mix was used as a blank control. Separate rooms were used for i. DNA extraction, ii. PCR mix and primer preparation, iii. the adding of DNA from clinical samples and positive control; and iv. post-PCR agarose-gel electrophoresis analysis. DNA samples were assayed in duplicate and at least twice.

\section{RESULTS}

The first experiments were conducted using the DNA extracted from WHO reference strains to establish the genotype by RFLP-PCR, using the primer set IR1/IR2 and additional treatment with HhaI enzymes. Figure 1 shows the restriction patterns of the six WHO reference strains. $L$. (V.) guyanensis and L. (V.) braziliensis showed the same restriction profile. On the other hand, L. (L.) amazonensis, L. (L.) major and $L$. (L.) infantum had specific restriction profiles.

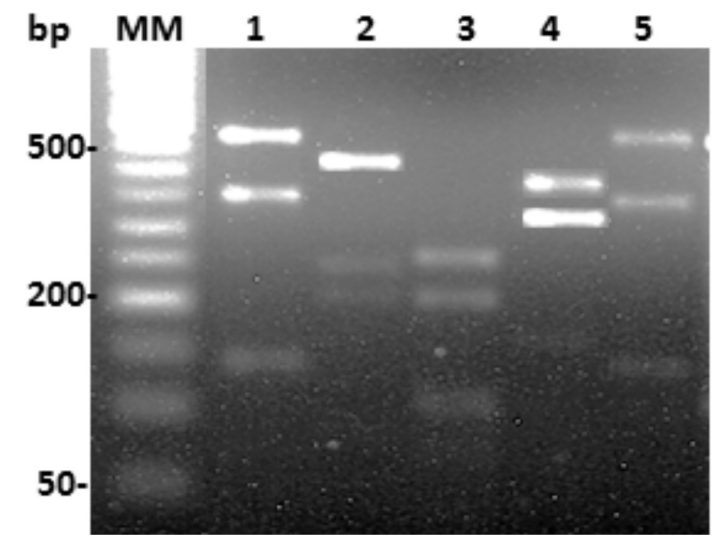

Fig. 1 - Restriction patterns of PCR products digested with HhaI in DNA extracted from standard Leishmania strains include the following: L. (V.) guyanensis (MHOM/BR/1975/ M4147) (1), L. (L.) amazonensis (IFLA/BR/1967/PH8) (2), L. (L.) major (MHOM/SU/1973/5ASKH) (3), L. (L.) infantum (MHOM/BR/1974/PP75) (4), and L. (V.) braziliensis (MHOM/ BR/1975/M2903) (5). Digested products were resolved in $2 \%$ agarose gel stained with ethidium bromide. MM, 50-bp ladder.
Next, genotype experiments were conducted on the 132 DNA samples taken from biopsies with a positive parasitological and molecular diagnosis. All samples also tested positive for L. (V.) braziliensis (in PCR), which was previously determined by the LU-5A/LB-3C primer set, whose products range in size from 146 to $149 \mathrm{bp}^{9,12,17}$. According the epidemiological registers of the Public Dermatology Clinics and Centers for Zoonosis Control, all samples analyzed were from patients or dogs with an autochthonous Leishmania infection (in the same locality as the biopsy collection).

Of the 132 DNA samples, only 52 (40\%) were successfully genotyped, as $1-1.2 \mathrm{~kb}$ products were amplified by the IR1/IR2 primer set. The other 80 samples were not genotyped, as PCR products were not amplified by this primer set. As expected, no amplification was detected in DNA extracted from DNA as a negative control and PCR products were obtained for all positive controls.

Table 1 shows the specification of the 52 genotyped samples in detail, which included the collection date of the biopsies (2003 - 2012), as well as the host (human or canine) and locality within the state of São Paulo. The 52 samples were distributed in nine distinct patterns, as shown in Figure 2.

Pattern 1 was identical to those found in $L$. (V.) guyanensis and $L$. (V.) braziliensis WHO reference strains (Fig. 1). Furthermore, this $L$. (V.) braziliensis pattern was the most common, since out of the 52 genotyped samples, $29(56 \%)$ belonged to pattern 1 and were distributed across 11 different municipalities. Pattern 2 was recurrent in nine samples distributed across three municipalities. The other patterns $(3-9)$ were uncommon and found in few samples: Pattern 3 (three municipalities), 4 (two municipalities), 5 (one municipality), 6 (one municipality), 7 (one municipality), 8 (two municipalities), 9 (two municipalities), respectively. The details and distribution of the clinical samples from the 44 human patients and eight dogs for each $L$. (V.) braziliensis isolate are shown in Table 2 and Figure 3. The majority (30) of the samples were from Sorocaba. The others (22) were distributed across the other 14 municipalities.

\section{DISCUSSION}

ATL has been growing worldwide in both incidence and range, principally due the increase in human migration. This mobility contributes

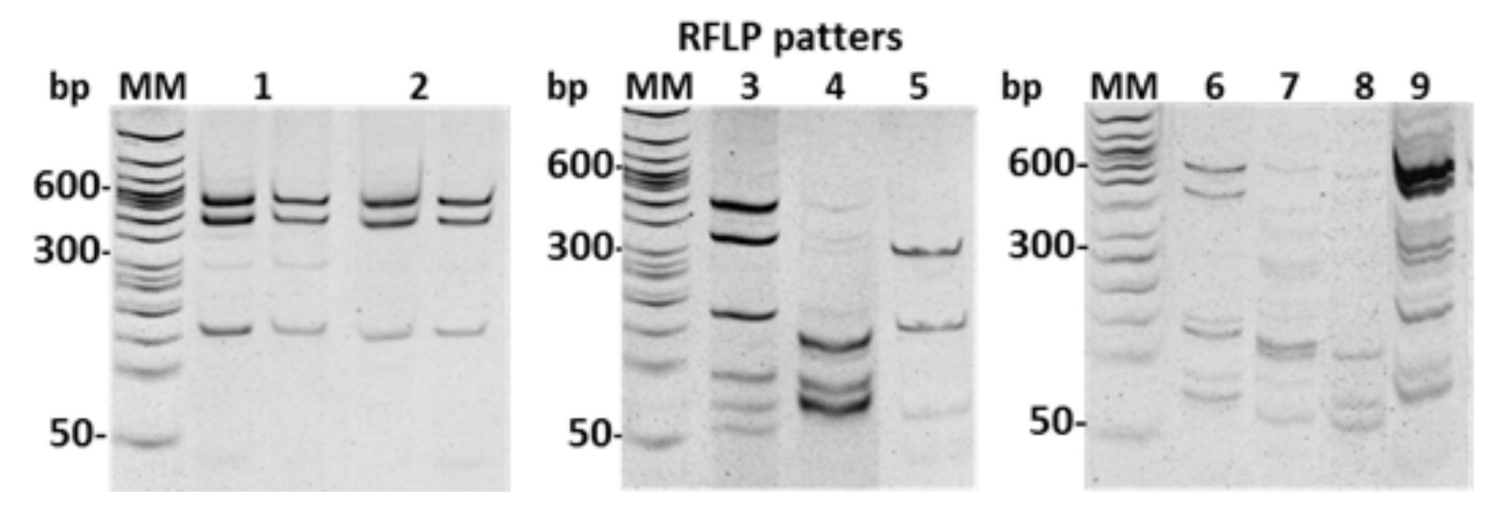

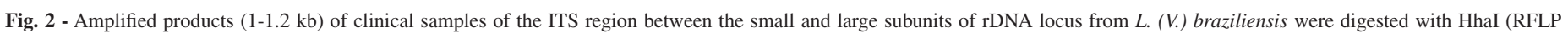

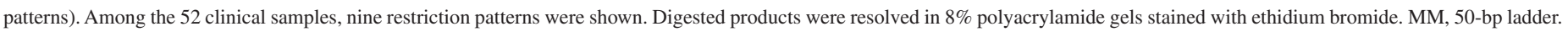




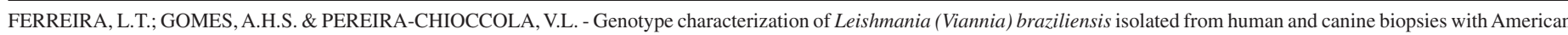
cutaneous leishmaniasis. Rev. Inst. Med. Trop. Sao Paulo, 57(3): 257-262, 2015.

Table 1

Clinical samples genotyped by RFLP-PCR in this study

\begin{tabular}{|c|c|c|c|c|c|}
\hline Sample code-month/year & Host & Municipality & Sample code-month/year & Host & Municipality \\
\hline 07-09/2003 & Human & Sorocaba & $1063-07 / 2008$ & Human & Sorocaba \\
\hline $18-09 / 2003$ & Human & Sorocaba & $1153-11 / 2008$ & Human & Campinas \\
\hline $20-09 / 2003$ & Canine & Sorocaba & $1324-02 / 2009$ & Human & Sorocaba \\
\hline $26-10 / 2003$ & Canine & Marilia & $1622-08 / 2009$ & Human & Sorocaba \\
\hline $64-09 / 2004$ & Human & Sorocaba & $1758-02 / 2010$ & Human & Jundiai \\
\hline $65-09 / 2004$ & Human & Sorocaba & $1945-06 / 2010$ & Human & Jundiai \\
\hline $84-11 / 2004$ & Canine & Ilha Bela & $1946-10 / 2010$ & Human & Jundiai \\
\hline $115-03 / 2005$ & Human & Sorocaba & $1985-11 / 2010$ & Human & Bauru \\
\hline $125-03 / 2005$ & Human & Sorocaba & $2001-12 / 2010$ & Human & Sorocaba \\
\hline $157-06 / 2005$ & Human & Itupeva & $2036-02 / 2011$ & Canine & Iporanga \\
\hline $194-08 / 2005$ & Human & Sorocaba & $2037-02 / 2011$ & Canine & Iporanga \\
\hline $253-11 / 2005$ & Human & Sorocaba & 2038-02/2011 & Canine & Iporanga \\
\hline $274-05 / 2006$ & Human & Mairiporã & $2072-04 / 2011$ & Human & Iperó \\
\hline $275-05 / 2006$ & Human & Cajamar & $2098-06 / 2011$ & Human & Sorocaba \\
\hline 279-05/2006 & Human & Itapera & $2135-09 / 2011$ & Human & Sorocaba \\
\hline $281-05 / 2006$ & Human & Sorocaba & $2136-09 / 2011$ & Human & Sorocaba \\
\hline $282-05 / 2006$ & Human & Sorocaba & $2150-09 / 2011$ & Human & Sorocaba \\
\hline $288-06 / 2006$ & Human & Itupeva & $2151-09 / 2011$ & Human & Sorocaba \\
\hline 304-08/2006 & Human & Sorocaba & $2152-09 / 2011$ & Human & Sorocaba \\
\hline $327-08 / 2006$ & Canine & Avaré & $2163-10 / 2011$ & Human & Sorocaba \\
\hline $354-10 / 2006$ & Human & Sorocaba & $2302-01 / 2012$ & Human & Sorocaba \\
\hline 504-09/2007 & Human & Sorocaba & $2538-05 / 2012$ & Human & Sorocaba \\
\hline $560-12 / 2007$ & Human & Sorocaba & $2656-07 / 2012$ & Human & Ribeira \\
\hline $684-03 / 2008$ & Human & Sorocaba & $2657-07 / 2012$ & Human & Ribeira \\
\hline $829-05 / 2008$ & Human & Sorocaba & $2658-07 / 2012$ & Human & Ribeira \\
\hline $832-05 / 2008$ & Canine & Caraguatatuba & $2883-12 / 2012$ & Human & Iperó \\
\hline
\end{tabular}

to the emergence of leishmanial infection in low or non-endemic areas ${ }^{13}$. To prevent new cases in these areas, epidemiological strategies must be implemented, such as rapid diagnosis, treatment and vector control. The importance of the study of genetic variability of Leishmania is mainly due to its correlation with the epidemiological aspects of the disease, such as geographic location, clinical forms, virulence, pathogenicity, drug resistance and antigenic variation, among others ${ }^{6,13}$.

Species belonging to the $L$. (V.) braziliensis sub-genera are highly prevalent in patients with ATL in Brazil. Other Brazilian studies have shown the genetic variability of these parasites, which would explain their adaptation to changes in diverse environmental conditions ${ }^{4,6}$. Thus, with such resilience, these parasites are more likely to infect multiple hosts. Although different genetic studies have analyzed $L$. (V.) braziliensis isolates from other Brazilian regions $s^{4,6,10,11,21,27}$, none have been conducted in the state of São Paulo.
The idea of conducting this study in the state of São Paulo was motivated by the state's increase of ATL incidences for the last 20 years. Currently, 147 municipalities have already recorded transmission. Thus, in this study, biopsies from $24.5 \%$ of these municipalities (36) were investigated. However, due to the low sensitivity of the IR1/IR2 primer set, samples from only 15 municipalities were genotyped.

One of the methods used to evaluate the genetic polymorphism of L. (V.) braziliensis isolates in different Brazilian regions is the analysis of RFLP in the internal transcribed spacers (ITS) of the ribosomal DNA (rDNA) locus. These studies have shown that molecular markers are suitable for population genetics and epidemiological studies ${ }^{4,5,6}$.

Despite the low sensitivity of the IR1/IR2 primer set and that the clinical samples presented a low quantity of parasites in comparison with culture isolates, $40 \%$ (52/132) of them were genotyped. Similar data 


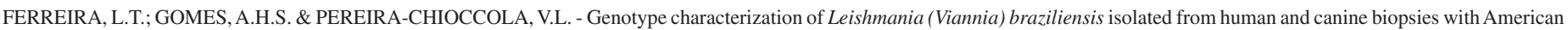
cutaneous leishmaniasis. Rev. Inst. Med. Trop. Sao Paulo, 57(3): 257-262, 2015.

Table 2

Distribution of the nine $L$. (V.) braziliensis profiles isolated from human and canine clinical samples in 15 municipalities of the state of São Paulo

\begin{tabular}{|c|c|c|c|}
\hline $\begin{array}{l}\text { L. (V.) braziliensis } \\
\text { genotyping }(n)\end{array}$ & $\begin{array}{l}\text { Municipality } \\
(n=15)\end{array}$ & Human & Canine \\
\hline \multirow{11}{*}{ Pattern 1 (29 samples) } & Bauru & 1 & - \\
\hline & Cajamar & 1 & - \\
\hline & Caraguatatuba & - & 1 \\
\hline & Iperó & 2 & - \\
\hline & Iporanga & - & 2 \\
\hline & Itapera & 1 & - \\
\hline & Itupeva & 2 & - \\
\hline & Jundiai & 2 & - \\
\hline & Mairiporã & 1 & - \\
\hline & Ribeira & 2 & - \\
\hline & Sorocaba & 13 & 1 \\
\hline \multirow{3}{*}{ Pattern 2 (9 samples) } & Jundiai & 1 & - \\
\hline & Ribeira & 1 & - \\
\hline & Sorocaba & 7 & - \\
\hline \multirow{3}{*}{ Pattern 3 (3 samples) } & Avaré & - & 1 \\
\hline & Marilia & - & 1 \\
\hline & Sorocaba & 1 & - \\
\hline \multirow{2}{*}{ Pattern 4 (2 samples) } & Campinas & 1 & - \\
\hline & Sorocaba & 1 & - \\
\hline Pattern 5 (1 sample) & Sorocaba & 1 & - \\
\hline Pattern 6 (2 samples) & Sorocaba & 2 & - \\
\hline Pattern 7 (2 samples) & Sorocaba & 2 & - \\
\hline \multirow{2}{*}{ Pattern 8 (2 samples) } & Iporanga & - & 1 \\
\hline & Sorocaba & 1 & - \\
\hline \multirow{2}{*}{ Pattern 9 (2 samples) } & Ilha Bela & - & 1 \\
\hline & Sorocaba & 1 & - \\
\hline Total of samples & & 44 & 8 \\
\hline
\end{tabular}

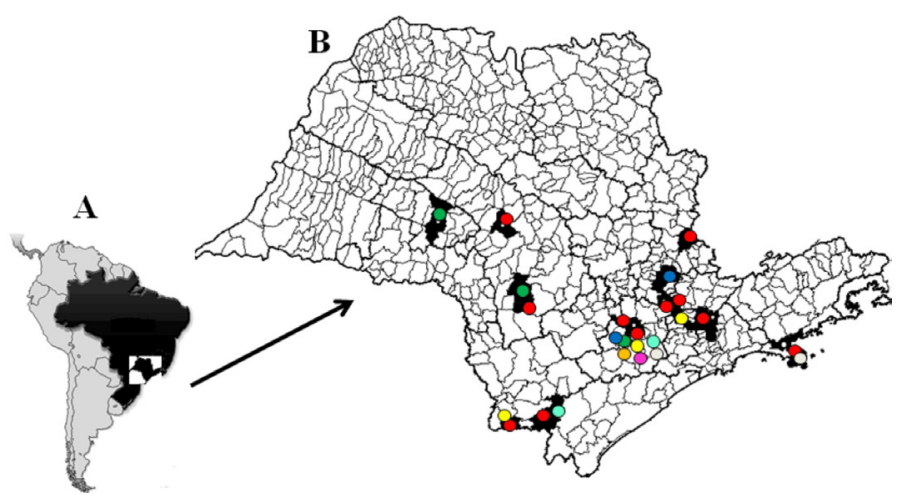

Fig. 3 - Map of South America and Brazil (A) indicating the location of the state of São Paulo (A). Map of the state of São Paulo (B) indicating the municipalities studied and geographical distribution of the L. (V.) braziliensis patterns: 1 (red), 2 (yellow), 3 (green), 4 (blue), 5 (purple), 6 (orange), 7 (pink), 8 (light blue) and 9 (gray). has previously shown ${ }^{20}$ the possibility of performing RFLP-PCR using small amounts of Leishmania DNA from host tissues. Consequently, it is possible to genotype Leishmania populations with the analysis of DNA extracted directly from clinical samples. This information is important, because in many laboratories there are no conditions in which to isolate and culture parasites from clinical samples ${ }^{20}$. Another interesting finding was the fact that DNA samples isolated 11 years ago (2003) were of good quality and could be used to genotype $L$. (V.) braziliensis isolates, as shown in Table 1.

Results showed that $L(V$.) braziliensis seems to be a species with great genetic diversity, as nine different patterns were observed in 52 different DNA samples from 15 municipalities using PCR-RFLP. As shown in Figure 3, the different $L(V$.) braziliensis patterns were spread throughout the regions. This genetic variability has already been shown in other Brazilian studies ${ }^{4,10,11,21,27}$. Additionally, the parasite polymorphism was correlated with different clinical forms of the disease, effectiveness of treatment and cytokines expression ${ }^{10,21,27}$.

According to other studies ${ }^{4,6,23,29}$, genotypic variations exhibited by $L(V$.) braziliensis could be explained by the adaption of parasites to changes in the transmission process, as originally, the biological cycle was restricted to forest environments. Similar to in other Brazilian regions, the gradual removal of vegetation has also occurred in São Paulo in recent years ${ }^{29}$. As a result, these parasites have adapted to infect a wider diversity of sand flies and reservoirs.

\section{RESUMO}

\section{Caracterização genotípica de isolados de Leishmania (Viannia) braziliensis provenientes de biopsias de humanos e cães com leishmaniose tegumentar americana}

Introdução: A leishmaniose tegumentar americana (LTA) é causada pelo sub-gênero Leishmania (Viannia) braziliensis. A evolução da LTA resulta com a evolução das lesões iniciais. A diversidade genética de L. (V.) braziliensis em algumas áreas endêmicas brasileiras, como no estado de São Paulo, é pouco conhecida. Assim, este estudo teve como objetivo analisar a variabilidade genética de isolados de $L$. (V.) braziliensis coletados de biopsias de pacientes e cães com LTA no estado de São Paulo. Métodos: O diagnóstico da leishmaniose foi realizado por PCR. As 132 biópsias analisadas foram coletadas em diferentes regiões do Estado de São Paulo, Brasil (36 municípios). A caracterização genética de $L$. (V.) braziliensis foi realizada por RFLP-PCR utilizando DNA extraído das biopsias. O conjunto de iniciadores utilizado amplificou a região ITS de Leishmania. Resultados: Das 132 amostras analisadas, 52 (40\%) foram completamente genotipadas por RFLP-PCR (44 de pacientes e oito de cães). Os resultados mostraram nove padrões distintos. A maioria das amostras genotipadas foi de Sorocaba (30), e as demais foram distribuídas entre 14 outros municípios. O primeiro padrão foi mais frequente (29 amostras), seguido pelo padrão 2 (nove amostras), padrão 3 (três amostras). Padrões 4, 6, 7, 8 e 9 foram compostos de duas amostras de cada um e o padrão 5 , com uma amostra. Conclusão: Estes resultados sugerem que cepas polimórficas de $L$. (V.) braziliensis circulam no estado de São Paulo. Estes dados são concordantes com estudos em outras regiões do Brasil, mostrando grande variabilidade destas populações naturais de focos endêmicos. 
FERREIRA, L.T.; GOMES, A.H.S. \& PEREIRA-CHIOCCOLA, V.L. - Genotype characterization of Leishmania (Viannia) braziliensis isolated from human and canine biopsies with American cutaneous leishmaniasis. Rev. Inst. Med. Trop. Sao Paulo, 57(3): 257-262, 2015.

\section{ACKNOWLEDGMENTS}

This study was supported by grants from the FAPESP (Fundação de Amparo à Pesquisa do Estado de São Paulo, Brazil). Proc2011/13939-8. L.T.F. was supported by a fellowship from CAPES (Coordenação de Aperfeiçoamento de Pessoal de Nível Superior, Brazil). V.L.P.C. was supported by a fellowship from CNPq (Conselho Nacional de Desenvolvimento Científico e Tecnológico, Brazil) Produtividade em Pesquisa, Proc. 303489/2012-0. Jim Hesson of AcademicEnglishSolutions.com proofread the English.

\section{REFERENCES}

1. Azulay RD, Azulay Junior DR. Immune-clinical-pathologic spectrum of leishmaniasis. Int J Dermatol. 1995;34:303-7

2. Carvalho EM, Barral A, Costa JM, Bittencourt A, Marsden P. Clinical and immunopathological aspects of disseminated cutaneous leishmaniasis. Acta Trop. 1994;56:315-25.

3. Colombo FA, Odorizzi RM, Laurenti MD, Galati EA, Canavez F, Pereira-Chioccola VL. Detection of Leishmania (Leishmania) infantum RNA in fleas and ticks collected from naturally infected dogs. Parasitol Res. 2011;109:267-74.

4. Cupolillo E, Brahim LR, Toaldo CB, Oliveira-Neto MP, Brito ME, Falqueto A, et al. Genetic polymorphism and molecular epidemiology of Leishmania (Viannia) braziliensis from different hosts and geographic areas in Brazil. J Clin Microbiol. 2003;41:3126-32

5. Cupolillo E, Grimaldi Júnior G, Momen H, Beverley SM. Intergenic region typing (IRT): a rapid molecular approach to the characterization and evolution of Leishmania. Mol Biochem Parasitol. 1995;73:145-55.

6. Cupolillo E, Momen H, Grimaldi G Jr. Genetic diversity in natural populations of New World Leishmania. Mem Inst Oswaldo Cruz. 1998;93:663-8.

7. Desjeux P. The increase in risk factors for leishmaniasis worldwide. Trans R Soc Trop Med Hyg. 2001;95:239-43.

8. Fernandes O, Bozza M, Pascale JM, Miranda AB, Lopes UG, Degrave WM. An oligonucleotide probe derived from kDNA minirepeats is specific for Leishmania (Viannia). Mem Inst Oswaldo Cruz. 1996;91:279-84.

9. Garcia AL, Parrado R, De Doncker S, Bermudez H, Dujardin JC. American tegumentary leishmaniasis: direct species identification of Leishmania in non-invasive clinical samples. Trans R Soc Trop Med Hyg. 2007;101:368-71.

10. Garcia L, Kindt A, Bermudez H, Lianos-Cuentas A, De Doncker S, Arevalo J, et al. Culture-independent species typing of neotropical Leishmania for clinical validation of a PCR-based assay targeting heat shock protein 70 genes. J Clin Microbiol. 2004:42:2294-7.

11. Gomes AH, Armelin IM, Menon SZ, Pereira-Chioccola VL. Leishmania (V.) braziliensis: detection by PCR in biopsies from patients with cutaneous leishmaniasis. Exp Parasitol. 2008;119:319-24.

12. Gomes AH, Ferreira IM, Lima ML, Cunha EA, Garcia AS, Araujo MF, et al. PCR identification of Leishmania in diagnosis and control of canine leishmaniasis. Vet Parasitol. 2007;144:234-41.

13. Gontijo B, de Carvalho M de L. Leishmaniose tegumentar Americana. Rev Soc Bras Med Trop. 2003;36:71-80.

14. Goto H, Lindoso JA. Current diagnosis and treatment of cutaneous and mucocutaneous leishmaniasis. Expert Rev Anti Infect Ther. 2010;8:419-33.
15. Goto H, Lindoso JA. Cutaneous and mucocutaneous leishmaniasis. Infect Dis Clin North Am. 2012;26:293-307.

16. Grimaldi G Jr, Tesh RB. Leishmaniasis of the New Word: current concepts and implications for the future research. Clin Microbiol Rev. 1993;6:230-50.

17. Harris E, Kropp G, Belli A, Rodriguez B, Agabian N. Single-step multiplex PCR assay for characterization of New World Leishmania complexes. J Clin Microbiol. 1998;36:1989-95.

18. Lainson R, Shaw JJ. New world leishmaniasis: the neotropical Leishmania species. In: Collier L, Balows A, Sussman M, editors. Topley \& Wilson's microbiology and microbial infections. $9^{\text {th }}$ ed. London: Arnold, 1998. p. 241-66.

19. Madeira MF, Uchôa CM, Leal CA, Silva RM, Duarte R, Magalhães CM, et al. Leishmania (Viannia) braziliensis em cães naturalmente infectados. Rev Soc Bras Med Trop. 2003;36:551-5.

20. Motoie G, Ferreira GE, Cupolillo E, Canavez F, Pereira-Chioccola VL. Spatial distribution and population genetics of Leishmania infantum genotypes in São Paulo State, Brazil, employing multilocus microsatellite typing directly in dog infected tissues. Infect Genet Evol. 2013;18:48-59.

21. Oliveira GM, Madeira MF, Oliveira FS, Pires MQ, Pacheco RS. Canine cutaneous leishmaniasis: dissemination and tissue tropism of genetically distinct Leishmania (Viannia) braziliensis populations. Vet Med Int. 2013;2013:982183.

22. Pan American Health Organization. Leishmaniases: epidemiological report of the Americas. PAHO; 2013. [Cited Jan 2014]. Available at: http://www.paho.org/hq/ index.php?option $=$ com_docman\&task $=$ doc_view\&gid $=21608 \&$ Itemid $=\% 20$

23. Passos VM, Fernandes O, Lacerda PA, Volpini AC, Gontijo CM, Degrave W, et al. Leishmania (Viannia) braziliensis is the predominant species infecting patients with American cutaneous leishmaniasis in the state of Minas Gerais, Southeast Brazil. Acta Trop. 1999;72:251-8.

24. Queiroz A, Sousa R, Heine C, Cardoso M, Guimarães LH, Machado PR, et al. Association between an emerging disseminated form of leishmaniasis and Leishmania (Viannia) braziliensis strain polymorphisms. J Clin Microbiol. 2012;50:4028-34.

25. Reimão JQ, Colombo FA, Pereira-Chioccola VL, Tempone AG. In vitro and experimenta therapeutic studies of the calcium channel blocker bepridil: detection of viable Leishmania (L.) chagasi by real-time PCR. Exp Parasitol. 2011;128:111-5.

26. Rioux JA, Lanotte G, Serres E, Pratlong F, Bastien P, Perieres J. Taxonomy of Leishmania. Use of isozymes. Suggestions for a new classification. Ann Parasitol Hum Comp. 1990;65:111-25

27. Schriefer A, Schriefer AL, Góes-Neto A, Guimarães LH, Carvalho LP, Almeida RP, et al. Multiclonal Leishmania braziliensis population structure and its clinical implication in a region of endemicity for American tegumentary leishmaniasis. Infect Immun. 2004; $72: 508-14$

28. Shaw JJ. Taxonomy of the genus Leishmania: present and future trends and their implications. Mem Inst Oswaldo Cruz. 1994;89:471-8.

29. Silva RA, Mercado VT, Henriques LF, Ciaravolo RM, Wanderley DM. Magnitude and trend of American tegumentary leishmaniasis in the State of São Paulo, Brazil, 1975 to 2008. Rev Bras Epidemiol. 2012;15:617-26.

30. World Health Organization. Leishmaniasis: Fact sheet $N^{\circ}$ 375, updated January 2014 WHO; 2014. [Cited Feb 2014]. Available from: http://www.who.int/mediacentre/ factsheets/fs375/en/index.html

Received: 23 June 2014

Accepted: 24 September 2014 